\title{
自己図式と性格特性：2つの性格特性次元での 自己関連情報処理の比較1)
}

\author{
早稲田大学 \\ 古屋健
}

問題

近年, 社会的情報処理に打ける自己の役割について さまざまなアプローチが試みられている（たとえば, Kuiper \& Rogers, 1979; Rogers et al., 1977; Rogers et al., 1979; など)。特に, Markus (1977) が提起した 自己図式 (self-schema) の概念は，スクリプト (Abelson, 1981) やプロトタイプ (Cantor \& Mischel, 1979) などと並び，社会的認知過程を解明する鍵概念として注 目されてきた (Kendzierski, 1980; Miller, 1984; など)。 Markus (1977) によれば, 他のさまざまな事象や対象 に関する情報の処理過程で認知図式が重要な働きをして いるように，人はその過去経験に基づいて自己に関連す る情報を統合してそれらを処理するための図式，すなわ ち自己図式を形成し, それは自己に関連した情報の処理 効率を高め, 記憶を促進し, 行動説明や行動予測に役立 つばかりでなく, 何らかの理由で自己と関連のある他の 事象や対象の情報処理に屯影響を与えるとされる。実際, これまでの研究では, 自立一依存次元 (Markus, 1977), 性度次元 (Markus et al., 1982), 外向性一内向性次元 (Fong \& Markus, 1982) での自己図式の有無が自己や 他者に関する情報処理に大きな影響を与えることが明ら かにされている。

ところで, 自己図式は関連情報を効率良く処理するた めの認知構造であり, 単なる認知内容を意味する自己概 念とは異なった特徵を持っている。 Markus (1977) は これに関連して, 個人の自己記述や自己評定は, それが 自己図式から派生している場合にのみ個人の他の行動パ ターンと一致すると述べ, 自己記述や自己評定が自己図 式によって裹打ちされている場合と, そうでない場合が あることを示唆している。しかしながら, Markus らに よる一連の研究方法では, ある特性に関して極端な自己
評定をし, またその特性が重要であるとした被験者を自 己図式 (schematic) 群に, そうでない被験者を非自己 図式 (aschematic) 群に分類しており, 自己記述や自己 評定の内容から自己図式の有無が判定できるかのような 手続きがとられている。そのために, ある性格特性につ いて極端な自己記述や自己評定がなされてもその特性に 関する自己図式の効果か認められない場合がありうるか, またあるとすればどのような場合かといった, こてで示 唆された問題は実質的に未検討のままである。

では, 個人の自己記述や自己評定に現われる特性の中 で, どの特性が自己図式に統合され，また統合されない のであろうか。乙れは自己図式の形成過程にかかわる問 題であるといえよう。Markus (1977) によれば, 自己 図式は行動が自己または他者によって繰り返しカテゴリ 一化され評価されるととに由来するとされる。つまり, ある特性次元上で経験をカテゴリー化した頻度が高いほ どその特性は自己図式に統合されやすいということであ る。こてで経験のカテゴリ一化を, 自己の一定の潜在的 特性の表われとして経験を解釈するてとであるとするな らば，それは性格特性の自己推論と言い換えることがで きよう。その場合, 繰り返し自己推論された特性ほど自 己図式に統合される可能性が高いと考えることができる。 特性の識別性 (distinctiveness) がその特性次元での自 己関連情報の処理に影響を与えること示した Mueller et al. (1984) や Mueller et al. (1986) の知見は乙の考 え方を支持するものである。

しかし，特性の自己推論を規定する要因は識別性だけ ではない。たとえば Bem $(1967,1972)$ の自己知覚理論 によれば, 自己の内的状態に関する知識は自分の行動や その行動がなされた環境などの観察可能な外的手がかり に依存し，その意味で人は第三者と機能的に等しい立場 にあると仮定される。乙の視点に立つと, 特性は観察可

1) 本論文作成に当たり, 早稲田大学教育学部橋本仁司教授にで指導いただきました。また, 実験実施に当たって 早稲田大学教育学部竹下修司さんと秋月由紀さんに協力していただきました。こてに記して厚く感謝いたします。 
能な行動と結びついているほど推論の手がかりが多く, したがって自己推論が容易になると考えられる。また, 別の考え方として, 自己知覚理論とは反対仙私的な思考 や感情といった内的反応を重視する立場もある。Bem の理論です, 自己知覚がなされるのは内的手がかりが弱 く, 曖昧で, 解釈不可能な場合であるとする条件がある 通り, すべての特性推論が自己知覚によってなされるわ けではない。特に, Anderson らは行動的反応よりむし ろ私的な思考・感情といった内的反応の方が自己推論に 及ぼす影響は大きいと主張している (Anderson, 1984; Anderson \& Ross, 1984; Anderson et al., 1986)。 乙の観点からみれば, 自己知覚理論の主張とは逆に, 私 的な思考・感情が手がかりとなる特性ほど自己推論され やすいととになる。

さらに, 推論を導く手がかりの中には認知的に処理さ れやすいすのと処理しにくいものがある。Ross (1977) はその一例として, 反応や事象が起こらないてとの意味 する情報が軽視されやすいてとを指摘している。乙れは, 事象の発現 (occurrrence) と発現しないこと (unoccurrence) が内的特性を推論する上で等しい情報価を有 していても, 実際の推論や判断に対しては発現情報の方 が大きな影響を及ぼすととを意味する。Fazio et al. （1982）は行動の非発現情報が自己推論に影響を与えな いことを示し, 自己知覚過程においてての正の特徴効果 (feature-positive effect) が認められることを明らかに している。また，実証的な検討はなされていないあのの， 私的な思考・感情による自己推論過程においても同様な 正の特徵効果が認められるあのと期待できる。したがっ て, 観察可能な行動の発現あるいは私的な思考・感情の 発現と結びついた特性ほど自己推論されやすいと考える ことができる。

さて, これらの要因が特性の自己推論への影響を介し て自己図式形成に関与すると仮定すれば, 個人の自己記 述や自己評定に現われる特性のうち, (1)自己知覚理論に よれば観察可能な行動と結びついた特性, (2) Anderson によれば私的な思考・感情などの内的反応と結びついた 特性, (3)正の特徴効果によって事象の発現之結びついた 特性は自己図式に統合されている可能性が高いと予測す ることができる。

そこで, 本研究では Eysenck の性格理論におりる外 向性次元之神経症的傾向次元を対象に以上の仮説の検討 を試みた。MPI 研究会 $(1969,1984)$ によれば, これら 2 つの性格特性はモーズレイ性格検查 (以下, MPI と略 記）によって測定され，相互に独立であるとされる。ま た, 外向性性格の強い人は社交的, 開放的で動作や感情
表出にためらいのない傾向が強く, 内向性性格はそれと は反対に引込み思案で人づきあいをさける傾向によって 特徵づけられる。乙の記述から明らかなように，一般に 外向性一内向性は社会的活動の特徴を手がかりにして推 論される特性であると言えよう。一方, 神経症的傾向に ついては, 過敏, 神経質, 落ち着きがない, 緊張が高い といった情緒不安定性が特徵として上げられる。乙れが 特定の行動よりむしろ内的な情動経験と深く関連してい ることは明らかである。また, 外向性と内向性, および 神経症的傾向之非神経症的傾向において, それぞれ前者 は社会的活動または内的情動経験の発現によって, 後者 はその非発現によって特徴づけられる特性であると言え よう。したがって, てれら各特性の特徴から判断して, 各特性次元でのM P I の得点とその特性の自己図式の有 無について, 上記仮説より次のような実験仮説を導くて とができる。

実験仮説 1 ：（自己知覚理論の仮定より）外向性次元 で高得点（外向性）または低得点（内向性）の被験者は その特性を自己図式流合しているであろう。

実験仮説 2 : (Anderson の仮定より) 神経症的傾向 次元で高得点 (神経症的傾向) または低得点（非神経症 的傾向）の被験者はその特性を自己図式に統合している であろう。

実験仮説 $3:$ (正の特徵効果により) 外向性次元及び 神経症的傾向次元で低得点の被験者より高得点の被験者 の方がその特性を自己図式に統合しているであろう。

なお，ある特性が自己図式に統合されているか否かは， その特性についての形容語判断課題における反応内容 (自己記述的と判断された形容語数), 反応時間, および 判断の難易度評定の 3 つの測度から推定することができ る。反応内容は当該特性の判断における一貫性を, また 反応時間之難易度評定は当該特性に関連する情報処理の 効率を示す指標である。具体的には, ある特性が自己図 式に統合されている場合, その特性を表わす形容語は特 性次元上の反対特性を表わす形容語と比較して, 自己記 述的と判断されることが多く, また自己記述的と判断す るまでの反応時間が短く, かつ判断が容易であると評定 されるであろう。自己記述的ではないとする判断ではこ れと逆の傾向が見られるはずである。また, 特性が自己 図式に統合されていなりれば, その特性と反対特性の形 容語判断の結果にてのような違いは見られないであろう。

\section{実 験 I}

方法

被験者 被験者は大学生男子 27 人, 女子 20 人, 計 47 人 
古屋：自己図式之性格特性：2つの性格特性次元での自己関連情報処理の比較

Table 1

Stimulus-words Experiment I

\begin{tabular}{clll}
\hline \multicolumn{4}{c}{ Target traits } \\
\hline extraversion & introversion & neuroticism & $\begin{array}{c}\text { non- } \\
\text { neuroticism }\end{array}$ \\
\hline 外向的 & 内向的 & 神経質 & 大胆な \\
陽気な & 除気な & 心配性 & 鈍感な \\
活発な & おとなしい & 神経過幠 & ずぼらな \\
社交的 & 内気な & 感じやすい & のんきな \\
積極的 & 消極的 & 敏感な & 落ち着いた \\
明るい & 暗 い & 感傷的 & 平静な \\
多弁な & しかえめな & 興奮しやすい & 無頓着 \\
楽観的 & 無口な & いらいらした & 悠長な \\
活動的 & 悲観的 & 感情的 & 自制的 \\
衝動的 & 慎重な & こわがり & タフな \\
\hline
\end{tabular}

である。彼らは実験の前日または実験終了後に MPI を わたされててれを完成した。

刺激語 MPI 研究会 $(1969,1984)$ の記述の中から, 外向性性格（以下， $\mathrm{E}$ 特性之略記), 内向性性格（以下， I 特性之略記), 神経症的傾向 (以下, $\mathrm{N}$ 特性之略記), および非神経症的傾向（以下，非 $\mathrm{N}$ 特性と略記）の特徴 を記述した形容語をそれぞれ10個ずつ拾い出した。形容 語リストを Table 1 に示す。実際に使用されたのは, 以上40個の形容語と，“冷たい”，“正直な”など上記性 格特性とは関連のないダミーの形容語 6 個を加えた 46 個 である。

装置 形容語判断課題の実施はすべてマイクロコンピ ュターによって統制された。教示は CRT 画面上に提示 され，被験者が理解していることを確認するために，被 験者には教示文を音読して不明な点は実験者に質問する よう指示した。形容語は黒地画面中央の $60 \mathrm{~mm} \times 30 \mathrm{~mm}$ の白い枠の中に白字で提示され, 提示前及び反応の後は 形容語提示部が $50 \mathrm{~mm} \times 15 \mathrm{~mm}$ の白帯で隱された。刺 激語提示に先立ち白枠の上部に 3 秒間“準備して下さい” という文字が赤字で提示され，その文字が消えた後に刺 激語が提示された。準備の文字が消えてから刺激語提示 までの間隔は 2 秒から 4 秒の間でランダムに変化した。 反応はすべて 2 件法で専用の反応装置が使用され, 被験 者は右手または左手でボタンを押すてとによって反応し た。反応時間（以下， RT と略記）の測定単位は $\mathrm{msec}$ である。

手続き 実験は “反応時間に関する研究” のための屯 のであると説明され，被験者は個別に実験に参加した。 彼らは CRT 画面装置と反応ボタンの前に着席し, 練習 試行の後, 本試行に入った。

練習試行：刺激語として“右”または “左”の文字が
ランダムに 3 回ずつ, 計 6 回提示され, 被験者はそれに 対応する側のボタンを押して反応した。

本試行: 本試行では, 画面に形容語が提示され, 被験 者はそれが自分にあてはまるから゙うか判断し，さらにそ の判断の難易度について評定するよう求められた。被験 者に与えられた教示は次の通りである。“これから本試 行を始めます。要領は先ほどの練習試行と同じです。た だし，今度は画面の中央に提示された言葉が自分にあて はまるかどうかを判断してもらいます。当てはまると思 う時は'Me'ボタンを, 当てはまらないと思う時は'Not -Me’ボタンを押して下さい。なお，訂正はできません から間違えないようにして下さい。また，一回一回判断 していただいた後に，今の判断が難しかったかどうかを 画面で質問します。隣のキーボードを用いて，1（やさ しかった）から5（むずかしかった）までの 5 段階で答 えて下さい”。

被験者が要領を理解したのを確認して本試行が始めら れた。半分の被験者は右手, 残りの半分は左手が “Me” ボタンとして指定された。40個の形容語の提示順序は被 験者ごとにランダムとされ，始めと終わりに 3 個ずつダ ミ一の刺激語が入れられた。ひとつの刺激語の提示時間 は最高 5 秒間でそれ以前に反応がなされると刺激語は白 帯で隠された。難易度評定にはコンピュターのキーボー ド上のテンキーを利用した。

\section{結果}

被験者の群分けと独立性の検討 MPI の外向性尺度 での得点 (以下, $\mathrm{E}$ 得点之略記) は $\mathrm{M}: 34.36, \mathrm{SD}: 10.79$, 神経症的傾向尺度での得点 (以下, $\mathrm{N}$ 得点之略記) は $\mathrm{M}$ : 20.68, SD: 12.99 であった。MPI 研究会 $(1969,1984)$ の資料と比較して, E得点で高く, $\mathrm{N}$ 得点で低い傾向が ある。本研究ではての 2 つの得点に従って, 被験者を 2 通りに群分けした。

E得点による群分けでは, MPI 研究会 $(1969,1984)$ の段階分けに従い，31点以下の 15 人（“やや内向的” 7 人及び“普通” 8 人）を低得点群, 32 点から 42 点の 21 人 （“やや外向的”）を中得点群，43点以上の11人（“非常に 外向的”）を高得点群とした。E得点の平均が高いため に, 低得点群に “普通”段階の被験者を含めざるを得な かった。したがって, 乙の場合, 低得点群は “内向性性 格”を意味しない。な扬，各群の $\mathrm{N}$ 得点の平均はそれぞ れ 25.73 (SD: 13.59), 18.43 (SD: 12.07), 18.09 (SD: $11.86)$ で有意な差は認められず $(F(2,44)=1.6806, p>$ .10)，神経症的傾向とは独立とみなすことができる。

同様に $\mathrm{N}$ 得点による群分けでは, 9 点以下の 10 人 (“神 経症的傾向はほとんどない”）を低得点群, 10点から29点 
Table 2

Number of responses, RT, and difficulty rating of self-judgment as a function of target trait words and E-scale score level for Exp. I

\begin{tabular}{|c|c|c|c|c|c|c|}
\hline \multirow{2}{*}{$\begin{array}{l}\text { Target trait words } \\
\text { E-scale scors }\end{array}$} & \multicolumn{3}{|c|}{ Extraversion } & \multicolumn{3}{|c|}{ Introversion } \\
\hline & Low & Middle & High & Low & Middle & High \\
\hline \multirow[t]{2}{*}{ Number of "Me" responses } & 3.5 & 7.6 & 9.3 & 6.5 & 3.0 & 1.5 \\
\hline & & & \multicolumn{2}{|c|}{ "Me" responses } & & \\
\hline $\mathrm{N}$ & 15 & 21 & 11 & 15 & 19 & 8 \\
\hline Reaction time (msec) & 1763.7 & 1165.2 & 1070.4 & 1411.0 & 1473.5 & 1770.0 \\
\hline \multirow[t]{2}{*}{ Difficulty ratings } & 2.5 & 2.4 & 1.8 & 2.5 & 2.7 & 3.1 \\
\hline & & & \multicolumn{2}{|c|}{ "Not-Me" responses } & & \\
\hline $\mathrm{N}$ & 15 & 16 & 4 & 14 & 21 & 11 \\
\hline Reaction time (msec) & 1453.3 & 1419.4 & 1478.8 & 1967.3 & 1361.4 & 1178.2 \\
\hline Difficulty ratings & 2.4 & 2.7 & 3.3 & 2.8 & 2.3 & 1.7 \\
\hline
\end{tabular}

の23人（“神経症的傾向は低い” 16 人及び “普通” 7 人) を中得点群, 30 点以上の 14 人 (“神経症的傾向がある” 8 人及び “神経症的傾向が非常に強い” 6 人）を高得点 群とした。乙の分類では中得点群にやや得点の低い被験 者が含まれているが, 高得点群は神経症的傾向が強く, 低得点群は神経症的傾向が低いと言える。各群の $\mathrm{E}$ 得点 の平均はそれぞれ 39.08 (SD: 5.77), 34.40 (SD: 11.70), 30.43 (SD: 11.25) で有意な差は認められなかった $(F$ $(2,44)=2.2732, p>.10)$ 。

$\mathrm{E}$ 特性一 $\mathrm{I}$ 特性次元での比較 $\mathrm{E}$ 得点水準各群の $\mathrm{E}$ 形 容語と I 形容語に対する “ Me” 反応数, RT, 難易度評 定の平均を Table 2 亿示した。一部被験者数が異なっ ているのは, ある形容語群での反応が “ $\mathrm{Me}$ 反応また は “Not-Me” 反応に偏った被験者がいたためである。 これらの測度での結果は得点水準群 3 水準（高得点群, 中得点群, 低得点群) $\times$ 形容語 2 水準 ( $\mathrm{E}$ 特性, I 特性) の 2 要因分散分析により処理された（以下の分析む同様 である)。

“Me” 反応数の平均の結果では交互作用が認められ $(F(2,88=44.6102, p<.01)$, 単純効果を分析した結果, 高得点群と中得点群では I 形容語より $\mathrm{E}$ 形容語で多く, 低得点群では $\mathrm{E}$ 形容語より I 形容語で多かった（いずれ 屯 $p<.01)$ 。したがって, 被験者の反応は得点水準に対 応していたと言える。また, 形容語の主効果す有意とな り $(F(1,88)=42.3037, p<.01)$, I 形容語より $\mathrm{E}$ 形容語 で “Me” 反応数が多かった。

$\mathrm{RT}$ と難易度評定については, “Me” 反応と “Not$\mathrm{Me}$ ”応とに分けて分析した (RT の検定には対数変換 值を用いた)。その結果, “Me” 反応の $\mathrm{RT}(F(1,83)=$ $4.4072, p<.05)$ と難易度評定 $(F(1,83)=4.8265, p<$ .05) で形容語の主効果が認められた。反応数の場合と
合わせ, このような形容語の主効果は本来期待されたも のではなく, 被験者全体の $\mathrm{E}$ 得点の平均が高かったとと が影響したあのと思われる。

ところで, 情報処理の効率に及ぼす自己図式の効果に 関係するのはこの分析における交互作用である。分析の 結果によれば, “Me” 反応の RT $(F(2,83)=7.0187, p<$ $.01)$ と “Not-Me” 反応の難易度評定 $(F(2,75)=4.2903$, $p<.05)$ で交互作用が有意となり, また “ $\mathrm{Me}$ ” 反応の 難易度評定 $(F(2,83)=2.6458, p<.08)$ と “Not-Me” 反応の RT $(F(2,83)=3.0051, p<.06)$ での交互作用屯 有意に近い水準を示している。乙れらの交互作用につい て単純効果を検定したとてろ, 高得点群は I 形容語より E形容語に対する “Me” 反応で $\mathrm{RT}$ が短く, またより 容易であったと評定しており，また $\mathrm{E}$ 形容語に対する “Not-Me” 反応はより難しかったと評定していた。低 得点群では $\mathrm{E}$ 形容語より I 形容語に対する “Not-Me” 反応で RT が長くなっていた。

以上の結果から, 高得点群には $\mathrm{E}$ 特性の自己図式の効 果が認められたが, 低得点群では I 特性の自己図式の効 果は認められていないと言うことができる。ただし，乙 の点については実験手続きに関連していくつかの問題点 を指摘できる。まず第 1 亿, 既に触れた通り, 本実験で は被験者の $\mathrm{E}$ 得点の分布が偏っていたために I 特性の強 い被験者が少く, 低得点群に “普通” と判定される被験 者を含めざるを得なかった点である。そのため, 本実験 の低得点群の結果は必ずしも I 特性が強い人の反応傾向 を表わしているとは言えない。第 2 亿, 一方の特性の形 容語に対する反応が “ Me” 反応または “Not-Me” 反応 に集中する傾向が強く, 特に高得点群では 7 人の被験者 が $\mathrm{E}$ 形容語に対してすべて “Me” 反応を示し, “Not$\mathrm{Me}$ 反応の資料が得られたのがわずか 4 人になってし 
古屋 : 自己図式と性格特性：2つの性格特性次元での自己関連情報処理の比較

Table 3

Number of responses, RT, and difficulty rating of self-judgment as a function of target trait words and N-scale score level for Exp. I

\begin{tabular}{|c|c|c|c|c|c|c|}
\hline \multirow{2}{*}{$\begin{array}{l}\text { Target trait words } \\
\text { N-scale score }\end{array}$} & \multicolumn{3}{|c|}{ Neuroticism } & \multicolumn{3}{|c|}{ Non-neuroticism } \\
\hline & Low & Middle & High & Low & Middle & High \\
\hline \multirow[t]{2}{*}{ Number of "Me" responses } & 3.7 & 4.4 & 8.1 & 6.7 & 5.9 & 5.0 \\
\hline & & \multicolumn{5}{|c|}{ "Me" responses } \\
\hline $\mathrm{N}$ & 10 & 22 & 14 & 10 & 23 & 14 \\
\hline Reaction time (msec) & 1474.8 & 1532.0 & 1345.8 & 1222.4 & 1406.0 & 1565.9 \\
\hline \multirow[t]{2}{*}{ Difficulty ratings } & 2.6 & 2.8 & 2.0 & 2.8 & 2.3 & 2.5 \\
\hline & \multicolumn{6}{|c|}{ "Not-Me" responses } \\
\hline $\mathrm{N}$ & 10 & 23 & 11 & 10 & 22 & 14 \\
\hline Reaction time (msec) & 1453.0 & 1552.9 & 2099.7 & 2065.6 & 1740.2 & 1813.6 \\
\hline Difficulty ratings & 2.9 & 2.6 & 3.6 & 2.5 & 2.9 & 3.1 \\
\hline
\end{tabular}

まったてとである。したがって, 以上の結果については さらに再検討する必要があるといえよう。

$N$ 特性一非 $N$ 特性次元での比較 $N$ 得点各群の $N$ 形容 語と非 N形容語判断課題を Table 3 亿示した。“Me” 反 応数の分析結果では, N得点水準の主効果 $(F(2,88)=$ $4.8439, p<.05)$ 之交互作用か認められた $(F(2,88)=$ 19.4396, $p<.01)$ 。主効果について多重比較により分 析したとてろ, 高得点群は他の 2 群より “ $\mathrm{Me}$ 反応数が 多かった $(p<.05)$ 。また, 交互作用について単純効果 を検定したとてろ, 低得点群では N 形容語より非 $\mathrm{N}$ 形容 語で “ Me” 反応が多く $(p<.01)$, 中得点群之高得点群 では非 N形容語より N形容語で “Me” 反応が多かった (中得点群で $p<.05$, 高得点群で $p<.01$ )。したがっ $\tau$, 各得点群の反応内容は $\mathrm{N}$ 得点水準に対応したもので あったと言える。

一方, $\mathrm{RT}$ 及び難易度評定の分析では, “Me” 反応及 び“Not-Me” 反応いずれに括いても有意な主効果, 交 互作用は認められなかった。したがって, N特性次元で は, たとえ MPI 得点が高くても, あるいは低くても, それに関連する情報処理に自己図式の効果は認められな いと言えよう。

\section{実 験 II}

実験 $\mathrm{I}$ では $\mathrm{E}$ 得点の分布の偏りと反応の偏りのために 仮説 1 亿ついて十分検討するてとができなかった。そて で, 実験 II では $\mathrm{E}$ 特性一 I 特性次元について再検討した。 方法は基本的に実験 I に準じたが，次の 2 点を变更した。 ひとつは刺激語として用いた形容語である。実験 I では MPI 研究会 $(1969,1984)$ の記述を中心に形容語を選択 したが，全体としてE形容語には社会的に望ましいすの が多く，それが反応の偏りの原因になったと思われる。
そこで実験 IIでは, 社会的望ましさの要因を考慮に入 れ, 日常生活で用いられている形容語によって刺激語を 構成した。なお, Semin \& Manstead (1981)によれば Eysenck の E 特性一 I 特性概念は一般の人が抱く性格 観ときわめて共通する部分が多いとされている。乙れは 英語圈ばかりでなく，日本語についてああてはまると思 われる。

あうひとつの変更点は, $\mathrm{E}$ 形容語判断と I 形容語判断 の過程における正の特徴効果を明らかにするために, 他 者についての判断課題を加えたてとである。既に述べた ように, てれらの特性推論が日常的な社会的行動の発現 ・非発現の情報に基づいてなされるならば, 正の特徵効 果によって E特性は I 特性より推論されやすいと予想さ れる。したがって, 他者判断では I 形容語より $\mathrm{E}$ 形容語 の方がより効率的に判断されるであろう。特に対象が未 知の人物で, 自己図式に対応するような関連情報を統合 した認知構造が形成されていない時ほどその効果は強い と考えられる。他方, 自己判断の場合, 日常生活で繰り 返し自己推論された特性ほど自己図式に統合されやすい と考えられることから，E特性が強い人では $\mathrm{E}$ 特性の自 己図式の効果が認められるのに対して，I 特性の強い人 では I 特性の自己図式の効果は認められないであろうと 予想される。

\section{方法}

被験者 大学生男子 19 人, 女子 25 人, 計 44 人である。 ほとんどの被験者は実験前日までに MPI を完成させた。 な技, 乙のうち 1 人の被験者は判断課題で誤反応が多か ったために以下の分析から除外した。

刺激語 実験 I で使用した形容語を中心に, その同意 語や反意語を加え, E形容語と I 形容語それぞれ20個ず つ選択し, 社会的望ましさが同じ程度になる 2 つのリス 
Table 4

Stimulus-words for Experiment II

\begin{tabular}{ll|ll}
\hline \multicolumn{2}{c|}{ extraversion } & \multicolumn{2}{c}{ introversion } \\
\hline list-A & list-B & list-A & list-B \\
愛想のよい & 活動的な & 控え目な & 穞やかな \\
陽気な & 積極的な & 落ち着いた & 遠慮深い \\
開放的な & 社交的な & 温厚な & おとなしい \\
元気のよい & 明るい & 内省的な & 慎重な \\
目立つ & 気安い & 静かな & つつましい \\
おしゃべな & 派手な & 地味な & 目立たない \\
うわっついた ずうずうしい & 孤独な & 閉鎖的な \\
騒々しい & 騒がしい & 引つ込み思案な & 㓌気な \\
衝動的な & 出しやばりな & 暗い & 無口な \\
軽率な & 落ち着きのない & うちとけない & 内気な \\
\hline
\end{tabular}

ト（リストAとリストB）を作成した。ひとつは自己判 断用, あうひとつは他者判断用である。リストを Table 4 亿示す。実際の課題では, $\mathrm{E}$ 特性, I 特性に関連のな い形容語10個と, リスト前後に置かれる 6 個のダミーを 加えて, 計36個の形容語が提示された。

手続き 実験装置及び練習試行は実験 I と同じである。 本試行は自己判断と他者判断から成り，被験者の半分は 自己判断から, 他の半分は他者判断から先に行なった。 また，形容語リストについても，2つのリストがそれぞ れ半数の被験者で自己判断用または他者判断用に当たる よう統制された。なお，リストの違いは結果に有意な影 響を与えていなかったので，以下の分析ではリスト要因 を除いてある。また, 選択ボタンの記述は “Me”, “Not -Me”ではなく“あてはまる”, “あてはまらない”とし， 全ての被験者で右手を“あてはまる” に指定した。他者 判断の場合の刺激人物としては，著名ではあるが性格特
性については多く知られていない人物として“(プロ野 球）西武球団の清原選手”を選んだ。

\section{結果と考察}

被験者の群分け MPI 研究会 $(1969,1984)$ の段階分 けに従って I ・ II 群に 1 段階（非常に内向的）および 2 段階（やや内向的）の 10 人，群に 3 段階（普通）の10 人, IV群に 4 段階（やや外向的）の 12 人，V群に 5 段階 （非常に外向的）の11人を当てた。

自己判断 自己を対象にした判断課題での反応数, RT 及び難易度評定の平均を Table 5 に示した。反応数の 分析では有意な交互作用が認められ $(F(3,78)=57.0704$, $p<.01)$, 単純効果を検定したとてろ, I ・ II 群と III群 では $\mathrm{E}$ 形容語より I 形容語で “あてはまる”反応が多く, $\mathrm{V}$ 群では I 形容語より $\mathrm{E}$ 形容語で多かった $(p<.01)$ 。 しかし，IV群では両者に有意な差はなかった $(p<.08)$ 。 したがって, 各得点群の反応内容はその $\mathrm{E}$ 得点水準を良 く反映していたと言えよう。

$\mathrm{RT}$ と難易度評定の結果について分析したとてろ, “あてはまらない” 反応の難易度評定以外の測度で $\mathrm{E}$ 得 点水準の主効果が認められた (“あてはまる” 反応の RT で $F(3,75)=2.6951, p<.05$, 難易度評定で $F(3,75)=$ $3.0423, p<.01$; “あてはまらない” 反応の難易度評定 で $F(3,75)=3.2313, p<.05)$ 。多重比較の結果, III 群 はV V群より “あてはまる” 反応の RT が長く, IV 群より 難しいと評定し, また, III群とIV群は他の 2 群より “あ てはまらない”反応の RT が長かった（いずれも $p<$ .05)。乙れらの結果は, 全般的に亚群ないしIV群のよう に $\mathrm{E}$ 得点が中程度の群において判断が難しかったてとを 示している。

一方，“あてはまる”反応の $\mathrm{RT}(F(3,75)=3.7532$,

Table 5

Number of responses, RT, and difficulty rating of self-judgment as a function of target trait words and E-scale score level for Exp. II

\begin{tabular}{|c|c|c|c|c|c|c|c|c|}
\hline \multirow{2}{*}{$\begin{array}{l}\text { Target trait words } \\
\text { E-scale score }\end{array}$} & \multicolumn{4}{|c|}{ Extraversion } & \multicolumn{4}{|c|}{ Introversion } \\
\hline & $\mathrm{I} \cdot \mathrm{II}$ & III & IV & $\mathrm{v}$ & $\mathrm{I} \cdot \mathrm{II}$ & III & IV & $\mathrm{V}$ \\
\hline \multirow[t]{2}{*}{$\begin{array}{l}\text { Number of } \\
\text { "Descriptive" responses }\end{array}$} & 1.9 & 3.4 & 5.4 & 7.6 & 7.6 & 5.8 & 4.3 & 1.6 \\
\hline & & & \multicolumn{4}{|c|}{ "Descriptive" responses } & & \\
\hline $\mathrm{N}$ & 8 & 10 & 12 & 11 & 10 & 10 & 12 & 10 \\
\hline Reaction time (msec) & 1921.5 & 2178.3 & 1371.0 & 1202.5 & 1588.4 & 1988.2 & 1960.0 & 1824.5 \\
\hline \multirow[t]{2}{*}{ Difficulty ratings } & 3.3 & 3.2 & 1.5 & 1.5 & 2.1 & 2.8 & 2.7 & 3.3 \\
\hline & & & \multicolumn{4}{|c|}{ "Non-dcscriptive" responses } & & \\
\hline $\mathrm{N}$ & 10 & 10 & 12 & 9 & 10 & 9 & 12 & 11 \\
\hline Reaction time (msec) & 1335.8 & 1803.5 & 1799.7 & 1590.3 & 1807.5 & 2096.6 & 2088.6 & 1479.2 \\
\hline Difficulty ratings & 2.3 & 2.2 & 2.6 & 2.3 & 2.3 & 2.9 & 2.2 & 2.5 \\
\hline
\end{tabular}


古屋：自己図式之性格特性：2つの性格特性次元での自己関連情報処理の比較

Table 6

Number of responses, RT, and difficulty rating of other-judgment as a function of target trait words and E-scale score level for Exp. II

\begin{tabular}{|c|c|c|c|c|c|c|c|c|}
\hline \multirow{2}{*}{$\begin{array}{l}\text { Target trait words } \\
\text { E-scale score }\end{array}$} & \multicolumn{4}{|c|}{ Extraversion } & \multicolumn{4}{|c|}{ Introversion } \\
\hline & $\mathrm{I} \cdot \mathrm{II}$ & III & IV & $\mathrm{V}$ & $\mathrm{I} \cdot \mathrm{II}$ & III & IV & V \\
\hline \multirow[t]{2}{*}{$\begin{array}{l}\text { Number of } \\
\text { "Descriptive" responses }\end{array}$} & 3.7 & 4.8 & 4.8 & 5.2 & 3.8 & 2.8 & 3.0 & 2.8 \\
\hline & & & \multicolumn{4}{|c|}{ "Descriptive" responses } & & \\
\hline $\mathrm{N}$ & 10 & 10 & 11 & 11 & 9 & 10 & 11 & 11 \\
\hline Reaction time (msec) & 1275.4 & 1683.5 & 1607.4 & 1433.8 & 1979.1 & 2434.7 & 2155.8 & 2230.2 \\
\hline \multirow[t]{2}{*}{ Difficulty ratings } & 1.8 & 2.3 & 1.7 & 2.6 & 3.3 & 3.1 & 3.4 & 3.0 \\
\hline & & & \multicolumn{4}{|c|}{ “Non-descriptive" responses } & & \\
\hline $\mathrm{N}$ & 10 & 10 & 12 & 10 & 10 & 10 & 12 & 11 \\
\hline Reaction time (msec) & 1487.7 & 1888.6 & 1568.1 & 1953.6 & 1658.4 & 1890.2 & 1691.0 & 1822.5 \\
\hline Difficulty ratings & 2.5 & 2.5 & 2.8 & 3.5 & 2.4 & 2.1 & 2.4 & 2.5 \\
\hline
\end{tabular}

$p<.05)$ と難易度評定 $(F(3,75)=10.5240, p<.01)$ で は期待された交互作用が認められた。単純効果の検定の 結果, 皿群では形容語間で有意な差は認められなかった が, IV群と V 群では I 形容語判断より $\mathrm{E}$ 形容語判断の方 が $\mathrm{RT}$ T短く, より容易であると評定されて打り, 自己 図式の効果が認められた。また I ・II群であ E 形容語判 断より I 形容語判断の方が容易であったと評定され, 自 己図式の効果が見られた。しかし, RT では有意な差は 認められず, 相対的に自己図式の効果はあまり強くない と言えよう。

他者判断 他者判断課題の結果 (Table 6) を分散分 析した結果, 反応数 $(F(1,78)=11.7615, p<.01)$, “あ てはまる” 反応の $\mathrm{RT}(F(1,75)=19.4258, p<.01)$ 及 び難易度評定 $(F(1,75)=17.7950, p<.01)$ で形容語の 主効果が認められ, I 形容語より $\mathrm{E}$ 形容語の方が “あて はまる” 反応が多く, RT が短く, また容易であったと 評定された。 $\mathrm{E}$ 得点水蕉の主効果之交互作用は認められ なかった。

なお，ての結果の解釈に当たっては, あとあと対象人 物についてE特性が強いという印象が持たれていたため に, 相対的に E 形容語の処理が促進されたという可能性 が考えられる。そてで, E得点水準要因に代えて, 反応 内容に基づき I 形容語で “あてはまる” 反応が多い内向 印象群 (11人), “あてはまる” 反応数が同じかあるいは $\mathrm{E}$ 形容語の方が I 形容語より 1 つまたは 2 つ多い弱外向 印象群 (14人), E形容語での “あてはまる” 反応が I 形 容語より 3 つ以上多い外向印象群（18人）の3 群に被験 者を分類し直して分散分析を行なった。その結果, やは り同様に“あてはまる” 反応の RT $(F(1,75)=17.7420$, $p<.01)$ と難易度評定 $(F(1,75)=14.5650, p<.01)$ で
形容語の主効果が認められただけで, 印象の主効果と交 互作用は認められなかった。したがって, 判断者自身の 特性傾向や対象人物に対する印象に関係なく, 他者判断 では I 形容語より $\mathrm{E}$ 形容語の方が効率良く処理されると 言うことができる。

\section{考}

本研究では, MPI の $\mathrm{E}$ 得点水準及び $\mathrm{N}$ 得点水準とそ の特性についての自己図式の有無との関連を検討した。 自己判断課題での反応内容はいずれの特性次元について 屯得点水準に良く対応していた。しかし， RT と判断難 易度評定の結果は特性によって異なったパターンを示し ている。E特性については, 実験 I, 実験 II を通じて E 得点の高い被験者群ほど I 形容語より $\mathrm{E}$ 形容語に対する 肯定判断が速くかつ容易になされ，乙れらの被験者にお いて $\mathrm{E}$ 特性が自己図式に統合されているてとが明らかに された。また, 実験 II では I 特性の強い群でむ $\mathrm{E}$ 形容語 より I 形容語の肯定判断が容易であると評定され, I 特 性の自己図式の効果が認められた。しかし, RTでは有 意な差か認められず, 相対的に I 特性については $\mathrm{E}$ 特性 より自己図式が形成されにくいととが示唆されている。 他方, $\mathrm{N}$ 特性一非 $\mathrm{N}$ 特性次元では $\mathrm{N}$ 得点水準と関連形容 語の自己判断の効率との間に期待された関係が見出せず ず, これらの特性次元で極端な自己記述や自己評価がな されても, それが自己図式によって裏打ちされている可 能性が低いことが示されている。

以上の結果を仮説に照して検討すると, まず $\mathrm{E}$ 特性と I 特性の強い群でその特性の自己図式の効果が確認され たととによって, 自己知覚理論 $(B e m, 1967,1972)$ か ら導かれた仮説 1 は支持されたと言えよう。しかし， N 
特性と非 $\mathrm{N}$ 特性については自己図式の効果が見出せず, Anderson ら (Anderson, 1984; Anderson \& Ross, 1984; Anderson et al., 1986) の主張に基づく仮説 2 は 支持されなかった。乙れは, ある特性について極端な自 己記述や自己評定がなされたとしても，その特性が自己 図式に統合されているとは限らないてとを意味する。特 に, 本研究の知見は観察可能な行動之結びついた特性は 私的な思考・感情などの内的反応と関連する特性より自 己図式に統合されやすいてとを示唆している。てれまで の研究で自立一依存次元や性度次元といった特性次元に おいて自己図式の効果が確認されてきたが，乙れらも $\mathrm{E}$ 特性一 I 特性次元同様, 一定の観察可能な行動傾向之関 連が深い特性であったてとがその結果に影響を与えてい た可能性がある。

また, 自己判断課題において E得点が低い被験者群よ り得点の高い被験者群で相対的に強い自己図式の効果が 見出されたことは, 仮説 3 を一部支持するあのである。 これに関連して, 実験 II の他者判断課題においても， E 形容語に対する肯定判断が I 形容語より速くかつ容易に なされており，E特性とI特性に関連する情報処理の過 程に一定のシステマティックなバイアスがかかっている てとを示唆している。乙てでは, 正の特徴効果がそのバ イアスの源泉であると解釈するてとができよう。ただし, 自己判断の結果に見られる相違はきわめて微妙で, 他者 を対象にした特性推論に示された相違ほど顕著でないと ころから, 乙の問題については自己判断過程と他者判断 過程の問題と合わせてさらに検討する必要がある。

と乙ろで, 仮説 2 が支持されなかったてとはいくつか の理由が考えられる。第 1 亿, Anderson らの言う内的 手がかりの意味が問題となる。たとえば, 彼らの実験で は言語化された感情や思考をもって内的手がかりとして いるが，それは私的な経験そのものではなく既にカテゴ リー化されたものである。つまり, 彼らの主張は言語的 にカテゴリー化された私的思考や感情は自己推論に大き な影響を与える，という意味で解釈すべきであろう。と ころが, 緊張, 興奮, 不安などN特性を特徵づける私的 な感情経験はきわめて多義的で, 必ずしもN特性次元上 での自己のカテゴリー化を導くとは限らない。そのため に, N特性を特徴づけるような私的経験が起てってむ, それが人によってあるいは状況によってさまざまにカテ ゴリー化されてしまい, その結果としてN特性は自己図 式に統合されにくいと考えることができる。

第 2 亿社会的望ましさの要因の影響を考える必要があ ろう。N特性が強いことは, そのととばが示す通り, 病 的な反応傾向が強いととを意味する。したがって, N特
性を特徴づける経験があっても, 自己防衛や自己高揚を 求める欲求によってN特性が強いという自己のカテゴ リー化が回避されてしまう可能性がある (Arkin et al., 1980; Zuckerman, 1979)。

さらに, 社会的なカテゴリー化の問題が上げられよ う。たとえば, 自己概念や自己評価は準拠集団や社会的 比較をする他者の特徴などによって大きな影響を受け ることが知られている (Festinger, 1954; McGuire \& Padawer-Singer, 1976)。Markus (1977) 屯示唆して いるように，乙れらの社会的要因は自己図式の形成過程 に大きな影響を与えるであろう。乙の観点に立つと, 他 者からの評価や社会的比較による自己評価を受ける頻度 が多いほど自己図式は形成されやすいてとになる。その 点, $\mathrm{E}$ 特性や I 特性と比較して N 特性は社会的場面との 関連が薄く, 社会的評価を受けにくい特性である。した がって, 自己推論の容易さではなく, 社会的評価を受け ることが少ないために，N特性は自己図式に統合されに くいと考えることができる。

社会的カテゴリー化の問題は本研究の $\mathrm{E}$ 特性次元での 結果の解釈に当たっても考慮に入れる必要がある。たと えば，E特性が自己図式に統合されやすいのは，それを 特徵づける行動が社会的な性質を有し, 社会的な評価を 受けることが多いといった事情が影響を与えている可能 性あある。特に, 自己知覚による推論がなされやすいと いうことは, 同時に他者によっても推論されやすいてと を意味している。したがって, E特性と結びついた観察 可能な行動的手がかりは自己知覚を介して自己図式の形 成を導くとも言えるし, あるいは社会的カテゴリー化を 経て自己図式の形成汇影響を与えると解釈するてとも可 能である。本研究では前者の視点に立って仮説を導き, 結果を解釈したが, てれらの要因の影響についてあ他の さまざまな特徴を持った諸特性について検討を加えるて とによって,さらに追求される必要がある。

\section{要約}

本研究では個人の中でどのような特性が自己図式に統 合されやすいかを検討する目的で, Eysency の E 特性 次元と N特性次元を対象に, MPI での反応とその特性 に関する自己図式の有無の関係について検討した。

実験 I では, E特性次元及びN 特性次元での MPI の 得点によって被験者を群分けし, それぞれの特性の特徵 を示した形容語の自己判断課題での成績を比較した。そ の結果, 反応内容は MPI の得点水準に対応した一貫性 を示していたが, 判断の処理効率に及ぼす自己図式の効 果について特性によって次のような違いが見られた。 


\section{古屋：自己図式と性格特性：2つの性格特性次元での自己関連情報処理の比較}

\section{E得点が高い被験者群では $\mathrm{E}$ 特性の自己図式の効} 果か認められた。しかし， E得点の分布が偏っていたた めに, E得点の低い被験者群で I 特性が自己図式に統合 されているかどうかは確認できなかった。

2. N得点水準は $\mathrm{N}$ 形容語及び非 $\mathrm{N}$ 形容語判断の効率 に影響を及ぼさず, $\mathrm{N}$ 特性, 非 $\mathrm{N}$ 特性とも自己図式に統 合されにくいことが示された。

実験 II では E 形容語・I 形容語の自己判断について日 常的な形容語を利用して再検討すると共に, 他者判断に ついてあ検討を加えた。結果は次の通りである。

1. 自己判断に扔いては, $\mathrm{E}$ 形容語及び I 形容語判断 と屯に自己図式の効果が認められたが，I 特性は相対的 にE特性より自己図式が形成されにくいととが示唆され た。

2. 他者判断の場合, I 特性より E特性判断で判断が 容易かつ速やかになされることが明らかにされた。

以上の結果は, 特性の自己推論過程との関連で考察さ れた。

\section{引用文 献}

Abelson, R. P. 1981 Psychological status of the script concept. American Psychologist, 36, 715-729.

Anderson, S. M. 1984 Self-knowledge and social inference: II. The diagnosticity of cognitive /affective and behavioral data. Journal of Personality and Social Psychology, 46, 294 -307 .

Anderson, S. M. \& Ross, L. 1984 Self-knowledge and social inferences: I. The impact of cognitive/affective and behavioral data. Journal of Personality and Social Psychology, 46, 280-293.

Anderson, S. M., Lazowski, L. E., \& Donisi, M. 1986 Salience and self-inference: The role of biased recollection in self-inference process. Social Cognition, 4, 75-95.

Arkin, R., Cooper, H. \& Kolditz, T. 1980 A statistical review of the literature concerning the self-serving bias in interpersonal influence situation. Journal of Personality, 48, 435-448.

Bem, D. J. 1967 Self-perception: An alternative interpretation of cognitive dissonance phenomena. Psychological Review, 74, 183-200.

Bem, D. J. 1972 Self-perception theory. In L. Berkowitz (ed.), Advances in experimental social psychology, vol.6. New York: Academic Press.

Cantor, N. \& Mischel, W. 1979 Prototypes in person perception. In L. Berkowitz (ed.), Advances in experimental social psycho$\log y$, vol.12. New York: Academic Press.

Fazio, R. H., Sherman, S. J., \& Herr, P. M. 1982 The feature-positive effect in the self-perception process: Dose not doing matter as much as doing? Journal of Personality and Social Psychology, 42, 404-411.

Festinger, L. 1954 A theory of social comparison processes. Human Relations, 7, 117-140.

Fong, G.T. \& Markus, H. 1982 Self-schemas and judgments about others. Social Cognition, 1, 191-204.

Kendzierski, D. 1980 Self-schemata and scripts: The recall of self-referent and scriptal information. Personality and Social Psychology Bulletin, 6, 23-29.

Kuiper, N. A. \& Rogers, T. B. 1979 Encoding of personal information: Self-other differences. Journal of Personality and Social Psycho$\log y, 37,499-514$.

Markus, H. 1977 Self-schemata and processing information about the self. Journal of Personality and Social Psychology, 35, 63-78.

Markus, H., Crane, M., Bernstein, S. \& Siladi, M. 1982 Self-schemas and gender. Journal of Personality and Social Psychology, 42, 3850.

McGuire, W.J. \& Padawer-Singer, A. 1976 Trait salience in the spontaneous self-concept. Journal of Personality and Social Psycho$\log y, 33,743-754$.

Miller,C.T. 1984 Self-schemas, gender, and social comparison: A clarification of the related attributes hypothesis. Journal of Personality and Social Psychology, 46, 1222-1229.

MPI 研究会 1969 新性格検査法一モーズレイ性格検 查一 誠信書房

MPI 研究会 1984 日本版モーズレイ性格検査手引誠 信書房

Mueller, J. H., Ross, M. J. \& Heesacker, M. 1984 Distinguishing me from thee. Bulletin of the Psychonomic Society, 22, 79-82.

Mueller, J. H., Thompson, W. B. \& Dugan, K. 1986 Trait distinctiveness and accessibility in the self-schema. Personality and Social Psychology Bulletin, 12, 81-89.

Rogers, T.B., Kuiper, N. A. \& Kirker, W.S. 1977 Self-reference and the encoding of personal information. Journal of Personality and Social Psychology, 35, 677-688.

Rogers, T. B., Rogers, P. J. \& Kuiper, N. A. 1979 Evidence for the self as a cognitive prototype: The "false alarms effect". Personality 
and Social Psychology Bulletin, 5, 53-56.

Ross, L. 1977 The intuitive psychologist and his shortcomings: Distortions in the attribution process. In L. Berkowitz (ed.), Advances in experimental social psychology, vol. 10. New York: Academic Press.

Semin, G. R., Rosch, E. \& Chassein, J. 1981 A comparison of the common-sense and 'sci- entific' conceptions of extraversion-intraversion. European Journal of Social Psychology, 11, 77-86.

Zuckerman, M. 1979 Attribution of success and failure revisited, or: The motivational bias is alive and well in attribution theory. Journal of Personality, 47, 245-287.

一1987年 4 月20日 受稿, 1987年 8 月 4 日 受理一

\title{
SELF-SCHEMATA AND PERSONALITY TRAITS: COMPARISON OF SELF-RELEVANT INFORMATION PROCESSING BETWEEN TWO PERSONALITY-TRAIT DIMENSIONS.
}

\author{
FURuYa TAKESHI \\ Waseda University
}

\section{ABSTRACT}

Two experiments were conducted to examine the relationship between the trait-scores of personality test (MPI) and the efficiency of selfreferent information processing on those traits. The results indicated that; (a) extraverted words led to more effective self-descriptive judgments than introverted ones in highly extraverted subjects; (b) subjects with low extraversion scalescores made self-descriptive judgments to intraverted words more easily than to extraverted
\end{abstract}

ones; (c) there was no difference in neurotic and non-neurotic subjects with regard to their processing efficiency of words relative to neuroticism and non-neuroticism; (d) judgments describing others took longer and were rated more difficult when prompted by introverted words than by extraverted ones. The findings suggested that personality traits associated with observable behaviors are more easily inferred and lead to self-schema formations than traits relating to internal affective cues.

Key words: social cognition, self, schema, personality, MPI 